\title{
Ultraviolet-absorbing compounds in the mucus of shallow-dwelling tropical reef fishes correlate with environmental water clarity
}

\author{
Jill P. Zamzow* \\ State of Hawaii, Division of Aquatic Resources, 2067 Omea Place, Honolulu, Hawaii 96821, USA \\ Present address: University of Alabama, Department of Biology, Birmingham, Alabama 35294-1170, USA
}

\begin{abstract}
Ultraviolet radiation is damaging to fishes, and fishes living in shallow water cope with this radiation by sequestering UV-absorbing compounds in their epithelial mucus. In the shallow waters of coastal Panama, fish may encounter vastly different irradiance environments that vary as a function of their proximity to major riverine inputs. Two common shallow water Caribbean fishes, Scarus iseri and Halichoeres bivittatus, were collected from 1 to $3 \mathrm{~m}$ depths at 3 locations within Bahia Almirante, Panama. Irradiance measurements were taken both at the subsurface and at $1 \mathrm{~m}$ depth for each of these sites, and $310 \mathrm{~nm}$ attenuation coefficients, $k_{\mathrm{d}}(310)$, ranged from $0.94 \mathrm{~m}^{-1}$ at the clearest site to $1.83 \mathrm{~m}^{-1}$ at the most turbid site. Fishes from waters where UV was attenuated the most quickly had mucous sunscreen that differed significantly from that of fishes from clearer waters. The 2 species showed different manners of acclimatizing to UV radiation: $H$. bivittatus from clearer waters shifted the spectral quality of its mucus toward absorbance of shorter, more damaging wavelengths, whereas $S$. iseri from clearer waters increased the overall UV absorbance of its mucus, with minimal spectral shifting.
\end{abstract}

KEY WORDS: UV · Fish · Mucus - Mycosporine-like amino acids · MAA · Turbidity · Attenuation coefficient

\section{INTRODUCTION}

Ultraviolet radiation (UV, 280 to $400 \mathrm{~nm}$ ) is damaging to fishes (Siebeck et al. 1994, Lesser et al. 2001, Zagarese \& Williamson 2001). Shallow-dwelling marine fishes possess UV-absorbing compounds in their mucus, presumably to protect them from harmful UV (Zamzow \& Losey 2002, Zamzow 2003, 2004). These UV-absorbing compounds, called mycosporine-like amino acids (MAAs), cannot be synthesized by animals and are obtained by fish through their diet (Mason et al. 1998, Shick \& Dunlap 2002, Zamzow 2004). Fish that are deprived of UVabsorbing compounds in the diet suffer higher rates of skin damage when exposed to solar UV (Zamzow 2004). UV-absorbing compounds have been found in the mucus of herbivorous, omnivorous, and carnivorous fishes (Zamzow \& Losey 2002), suggesting that these compounds are accumulated up the food chain.
The concentrations of UV-absorbing compounds found in the mucus of marine fishes vary according to environmental factors. UV absorbance of the mucus of a Hawaiian wrasse decreased with increasing depth of seawater (Zamzow \& Losey 2002), and the mucus of high-latitude tidepool sculpins absorbed less UV than that of conspecifics nearer the equator (Zamzow 2003). In laboratory experiments, the mucus of fish that were exposed to full solar UV radiation absorbed far more UV than that of freshly caught individuals, or that of experimental individuals exposed to photosynthetically active radiation (PAR, 400 to $700 \mathrm{~nm}$ ) alone (Zamzow 2004).

In tropical seas, the transmission of $310 \mathrm{~nm}$ ultraviolet light may range from 50 to $80 \% \mathrm{~m}^{-1}$ of seawater, but in coastal areas this value may drop to $10 \% \mathrm{~m}^{-1}$ or less (Jerlov 1968). The transmission of ultraviolet radiation through seawater is strongly influenced by absorbance owing to particles and humic substances in the water, 
such as occurs near river mouths (Jerlov 1968, Kirk 1994). Noting this variability in the optical properties of water in the far ultraviolet, Jerlov (1968) classified water into different optical types on the basis of irradiance transmission across the ultraviolet and visible spectrum. More recently, Kirk (1994) detailed a method of calculating the vertical attenuation of ultraviolet irradiance $\left(k_{\mathrm{d}}\right)$, and presented UVB vertical attenuation data at $310 \mathrm{~nm}$ for a number of different natural waters. These values ranged from $0.116 \mathrm{~m}^{-1}$ in clear oceanic water (Sargasso Sea) to $37.3 \mathrm{~m}^{-1}$ in the Yellow Sea.

The striped parrotfish Scarus iseri and the slippery dick Halichoeres bivittatus are abundant in the shallow coastal waters of Bocas del Toro, Panama. S. iseri is herbivorous, consuming cyanobacteria (Calothrix and Lyngbia spp.) and red and green algal species (Randall 1967). S. iseri individuals may show any of 3 behavioral types-territorial, stationary, or foraging - with corresponding home ranges of approximately 10,50, and $5000 \mathrm{~m}^{2}$ (Ogden \& Buckman 1973). While home-range size may vary, these fish rarely venture deeper than 3 m (Ogden \& Buckman 1973).

Halichoeres bivittatus is a generalist carnivore, consuming a wide variety of benthic species such as crabs, urchins, brittle stars, polychaete worms, molluscs, shrimps, chitons, stomatopods and bony fishes (Randall 1967, Wainwright 1988). A gradual ontogenetic dietary shift from primarily soft-bodied to primarily hard-bodied invertebrate prey occurs as fish grow from 8 to $11 \mathrm{~cm}$ standard length (Wainwright 1988). $H$. bivittatus shows high site fidelity, and home-range size correlates with fish size (Jones 2005). Initial phase adult fish like those sampled in this study possess small home ranges of approximately $30 \mathrm{~m}^{2}$, and spend $50 \%$ of their time in an area of less than $8 \mathrm{~m}^{2}$ (Jones 2005).

The suspended sediment load of rivers increases with their discharge rate (Newson 1994), and the amount of suspended sediment in the ocean decreases with distance from the river mouth (Lou \& Ridd 1997, Neil et al. 2002). I collected Panamanian fish from 3 coastal microhabitats (see Fig. 1) with different levels of freshwater input, and different particulate densities. I captured fish from habitats: (1) $\leq 5 \mathrm{~km}$ from 2 large mainland rivers (Rio Oeste and Quebrada Nigua at Punta de Gallinazo); (2) $\sim 15 \mathrm{~km}$ from the aforementioned rivers, and $100 \mathrm{~m}$ from the mouth of a small island stream (Quebrada Paloma); (3) 30 km from the rivers, with no nearby stream (Cayo Crawl). For each site, I measured irradiance, characterized the optical water type, and calculated the $310 \mathrm{~nm}$ attenuation coefficient. After measuring UV absorbance spectra for the mucus of fishes from each site, I tested the hypothesis that environmental turbidity and resultant UV penetration of the water column correlates with the UV absorbance of marine fish mucus.

\section{MATERIALS AND METHODS}

In November and December 2003, 40 Scarus iseri and 42 Halichoeres bivittatus were captured by snorkelers with barrier nets in the waters south of Isla Colon, Bocas del Toro, Panama. These species were chosen because of their local abundance in shallow depths. Fishes were collected from 3 sites (Fig. 1): Punta de Gallinazo $\left(9^{\circ} 15^{\prime} \mathrm{N}, 82^{\circ} 22^{\prime} \mathrm{W}\right)$, Quebrada Paloma $\left(9^{\circ} 17^{\prime} \mathrm{N}, 82^{\circ} 15^{\prime} \mathrm{W}\right)$, and Crawl Cay $\left(9^{\circ} 15^{\prime} \mathrm{N}\right.$, $\left.82^{\circ} 08^{\prime} \mathrm{W}\right)$. Fishes were captured at 2 to $3 \mathrm{~m}$ depths and kept in an aerated 'live well' while being transported to the Smithsonian Tropical Research Institute on Isla Colon. Mucus samples were taken from all fishes within $24 \mathrm{~h}$ of capture, and fishes were subsequently released into their native habitat. This work was conducted in accordance with institutional, national and international guidelines concerning the use of animals in research (IACUC Animal Care Protocol 95-012 University of Hawaii; available at: www.hawaii.edu/ansc/IACUC/index.html).

A sample of mucus was acquired from each individual by gently scraping the dorsal flank surface over an area of approximately $2 \mathrm{~cm}^{2}$ with a dulled scalpel blade (Zamzow \& Losey 2002, Zamzow 2003, 2004, Zamzow \& Siebeck 2006). The absorbance of mucus samples was measured following Zamzow \& Losey (2002). Briefly, mucus was 'squashed' between 2 UV-transparent slides with coverslips acting as $0.25 \mathrm{~mm}$ spacers between the slides. UV and visible light (250 to $1100 \mathrm{~nm}$ ) from a tungsten-deuterium source (Analytical Instruments) was passed through the sample and fed into a spectrophotometer (S-2000, Ocean Optics). Eight separate absorbance measurements were taken through each mucus sample. In order to compensate for mucus heterogeneity, measurements were consistently taken through the areas of highest UV absorbance found while scanning each sample.

Absorbance curves were plotted and a mean of the 8 curves for each fish obtained. This mean curve was used to calculate maximum $\lambda$ ( $\lambda_{\max }$, the wavelength of the highest point of the absorbance peak), and integrated UV absorbance (the area under the mean absorbance curve from 280 to $400 \mathrm{~nm}$, following Zamzow 2004). Integrated UV absorbance has no unit of measure, it is simply the sum of the absorbance values for each wavelength from 280 to $400 \mathrm{~nm}$. In other words, it is an approximation of the area under the UV absorbance curve. Integrated UV absorbance values and $\lambda_{\max }$ were analyzed via general linear model (GLM). GLMs first included an interaction term for fish length by site interactions, but because no interaction effects were found (all $p>0.1$ ), the interaction terms were removed from the final models. 


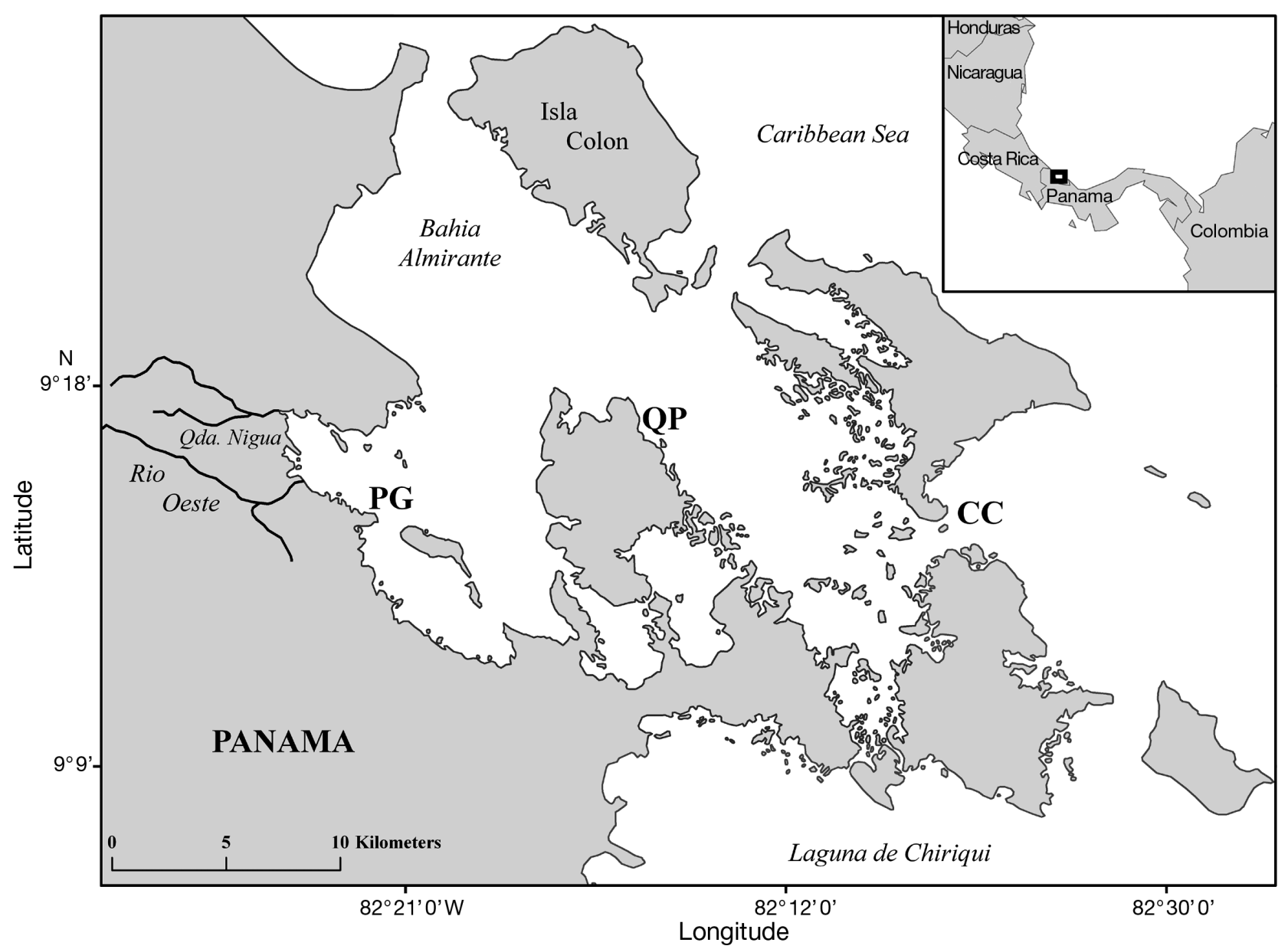

Fig. 1. Study area, showing study sites and rivers influencing the site at Punta de Gallinazo. The stream at Quebrada Paloma (QP) was too small to appear on this map. PG: Punta de Gallinazo; CC: Cayo Crawl

Ambient solar UV irradiance was measured for each of the 3 capture sites with a cosine corrector (CC-3, Ocean Optics) at the end of an optical fiber that led to the S-2000. The cosine corrector was calibrated prior to each set of measurements with an LS-1-CAL radiometric calibration standard (Ocean Optics). In the field, the cosine corrector was filled with local seawater before each set of measurements, and irradiance was measured immediately below the surface and at a depth of $1 \mathrm{~m}$ at each site (see Fig. 2). Because the measurements were taken on different days and at different times of day, the percentage of UV irradiance transmitted to depth was calculated by dividing the area under the depth curve by the area under the immediately subsurface curve.

The vertical attenuation coefficient at $310 \mathrm{~nm}, k_{\mathrm{d}}(310)$, was calculated from the irradiance data at the surface and at $1 \mathrm{~m}$ depth, following Eq. (1) in Kirk (1994). The corresponding $Z(10 \%)$, or the depth at which $10 \%$ of the surface UVB is present, was also determined following Kirk (1994).

\section{RESULTS}

\section{Irradiance}

Ultraviolet irradiance decreased with increasing depth of seawater in a site-specific spectral manner (Fig. 2). At Punta de Gallinazo, $34 \%$ of the total subsurface UV irradiance reached $1 \mathrm{~m}$ in depth, and the underwater irradiance spectrum at $1 \mathrm{~m}$ most closely resembled Jerlov Coastal Type 3. At Quebrada Paloma, $58 \%$ of the subsurface UV irradiance reached $1 \mathrm{~m}$, and the spectral distribution resembled Jerlov Coastal Type 1, with slightly elevated UV transmission. Cayo Crawl had the greatest light penetration with $65 \%$ of incident subsurface irradiance reaching $1 \mathrm{~m}$, and the irradiance spectrum indicated Jerlov Oceanic Type III water.

The vertical attenuation coefficients calculated for downward UVB irradiance at $310 \mathrm{~nm} k_{\mathrm{d}}(310)$, were: Punta de Gallinazo, $1.83 \mathrm{~m}^{-1}$; Quebrada Paloma, $1.17 \mathrm{~m}^{-1}$; Cayo Crawl, $0.94 \mathrm{~m}^{-1}$. The depths at which 

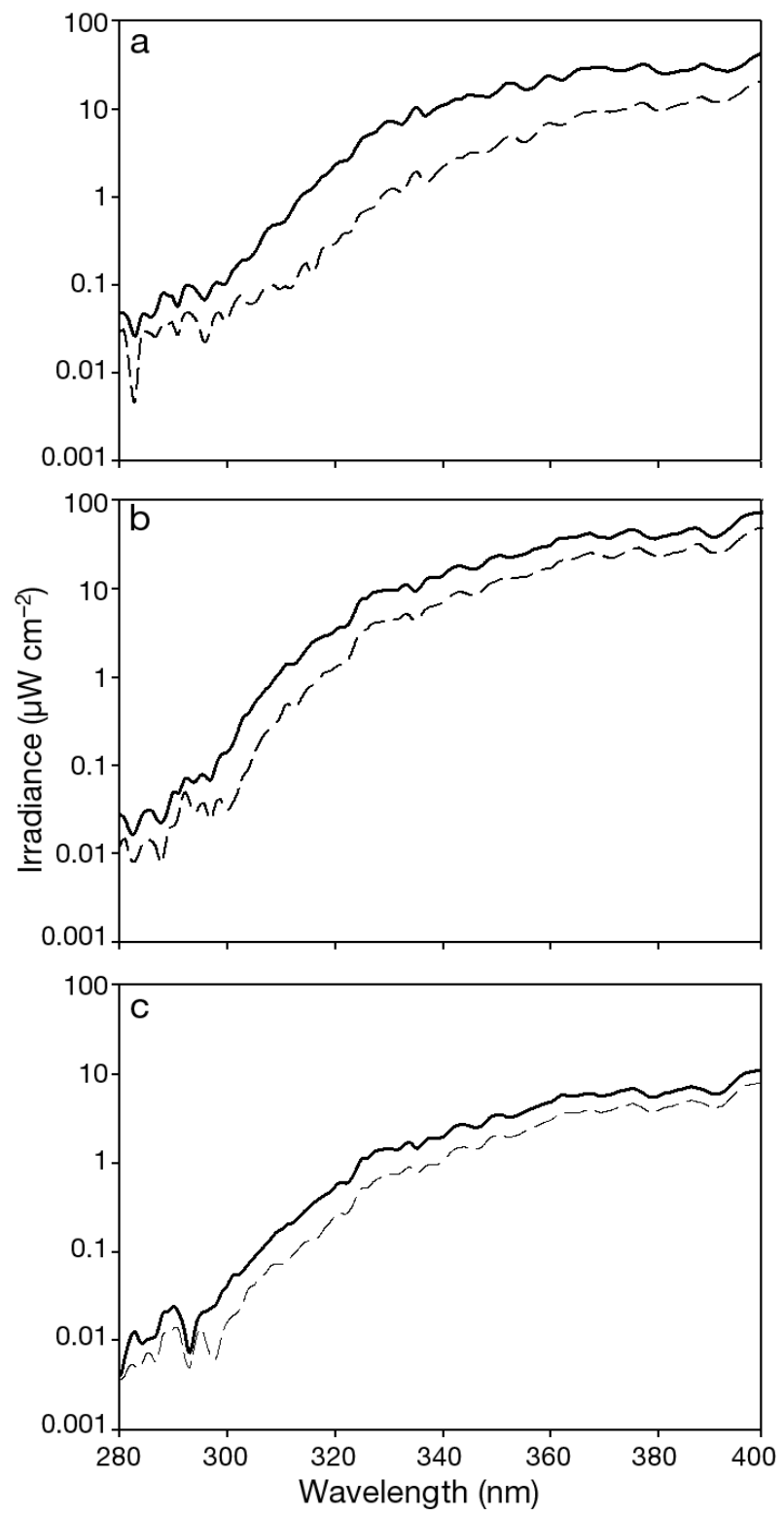

Fig. 2. UV irradiance spectra from 3 sites of fish capture. Heavy line: subsurface irradiance measurement; dashed line: irradiance at $1 \mathrm{~m}$ depth. (a) Punta de Gallinazo, (b) Quebrada Paloma, and (c) Cayo Crawl. Spectra in (c) were taken on a slightly overcast day, hence the reduction in overall irradiance

UVB irradiance was $10 \%$ of that just below the surface, $Z(10 \%)$, were as follows: Punta de Gallinazo, $1.8 \mathrm{~m}$; Quebrada Paloma, 3.4 m; Cayo Crawl, 4.4 m).

\section{Mucus absorbance}

The mucus of Halichoeres bivittatus and Scarus iseri contained UV-absorbing compounds (Fig. 3). The mucus of $H$. bivittatus was characterized by a single absorbance peak with $\lambda_{\max }$ ranging from 317 to $327 \mathrm{~nm}$, and a shorter-wavelength shoulder. The mucus of $S$. iseri had more complex UV absorbance spectra, with 1 clear primary peak and 2 shoulders (Fig. 3). The primary absorbance peak fell between 325 and $330 \mathrm{~nm}$, and 'shoulders', or secondary peaks, were observed at approximately 295 and $360 \mathrm{~nm}$. Overall, the mucus of $S$. iseri absorbed far more UV radiation than did the mucus of $H$. bivittatus.

\section{Halichoeres bivittatus}

Integrated UV absorbance of Halichoeres bivittatus mucus increased with increasing fish size (Fig. 4a; GLM: $F_{1,38}=7.90 ; \mathrm{p}<0.01 ; \mathrm{r}^{2}=0.21$ ), but did not differ by site of capture (Fig. $4 \mathrm{~b}$; GLM: $F_{2,38}=1.7$; $\mathrm{p}=0.1$ ).

The wavelength of maximum absorbance of Halichoeres bivittatus mucus did not correlate with fish size (Fig. 5a; GLM: $F_{1,38}=0.15 ; \mathrm{p}=0.7 ; \mathrm{r}^{2}=0.75$ ), but did differ by capture site (Fig. 5b). Fish from Cayo Crawl had a shorter wavelength $\lambda_{\max }$ than those from Quebrada Paloma, which in turn had a shorter wavelength $\lambda_{\max }$ than fish from Punta de Gallinazo (GLM: $F_{2,38}=57.8 ; \mathrm{p}<0.0001 ;$ Tukey's post-hoc).

\section{Scarus iseri}

Integrated UV absorbance of Scarus iseri mucus was related to fish size, and also differed among sites of capture (Fig. 6). Mucus absorbance increased with increasing fish size (GLM: $F_{1,36}=7.19 ; \mathrm{p}=0.01 ; \mathrm{r}^{2}=$ 0.66). Fish from Cayo Crawl had higher integrated UV absorbance than those from Quebrada Paloma, which in turn had higher integrated UV absorbance than fish

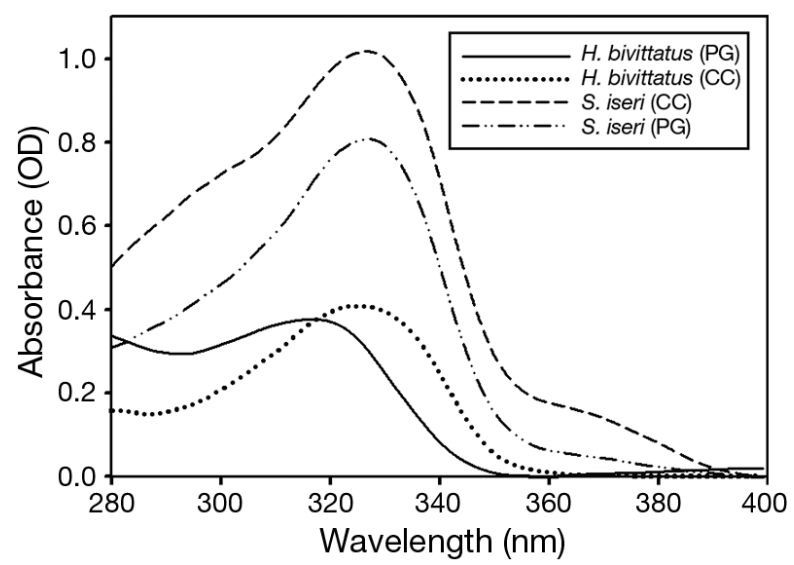

Fig. 3. Scarus iseri and Halichoeres bivittatus. Sample mucus spectra. CC: Cayo Crawl; PG: Punta de Gallinazo. Note: wavelength of maximum absorbance shifts between the $2 \mathrm{H}$. bivittatus curves, but not between $S$. iseri curves. OD: optical density 


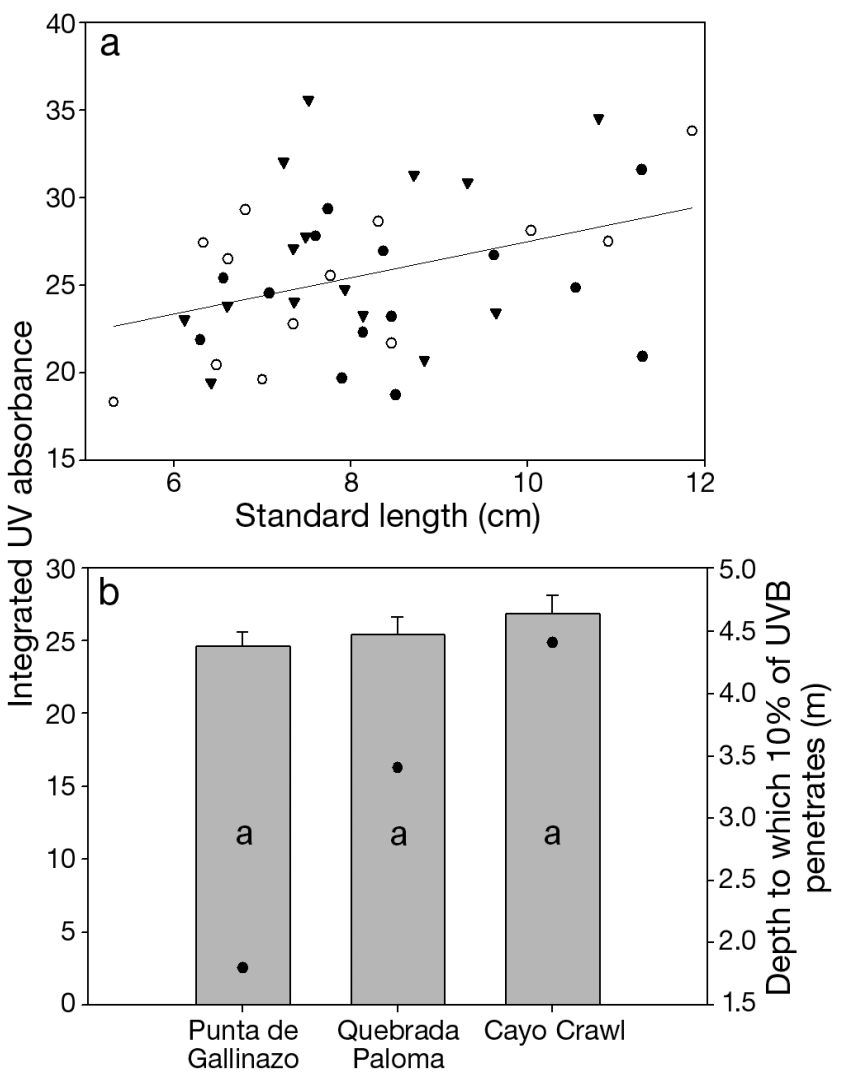

Fig. 4. Halichoeres bivittatus. Integrated UV absorbance of the mucus. (a) Standard length vs. integrated absorbance, by site of capture (general linear model, GLM: $F_{1,38}=7.9, \mathrm{p}<0.01$ ). $\bullet$ : Punta de Gallinazo; O: Quebrada Paloma; $\mathbf{\nabla}$ : Cayo Crawl. (b) Integrated UV absorbance of mucus (GLM: $F_{2,38}=1.7, \mathrm{p}=0.1$ ) and irradiance data. Bars: integrated absorbance (mean $+\mathrm{SE})$;

-: depth to which $10 \%$ of UVB irradiance penetrates. Letters on bars indicate statistically significant groupings

from Punta de Gallinazo (GLM: $F_{2,36}=35.1 ; \mathrm{p}<0.001$; Tukey's post-hoc)

The wavelength of maximum absorbance of Scarus iseri mucus did not correlate with fish size (Fig. 7a; GLM: $F_{1,36}=3.52 ; \mathrm{p}=0.07 ; \mathrm{r}^{2}=0.26$ ), but did differ among sites (Fig. 7b). Fish from Cayo Crawl had a shorter $\lambda_{\max }$ than those from Punta de Gallinazo, but no other differences among sites were detected (GLM: $F_{2,36}=3.61 ; \mathrm{p}<0.05 ;$ Tukey's post-hoc).

\section{DISCUSSION}

\section{Irradiance}

Riverine influence on turbidity and dissolved organic carbon levels, and subsequent attenuation of UV radiation by seawater, decreases with distance from the river mouth (Kirk 1994, Lou \& Ridd 1997, Højerslev \&

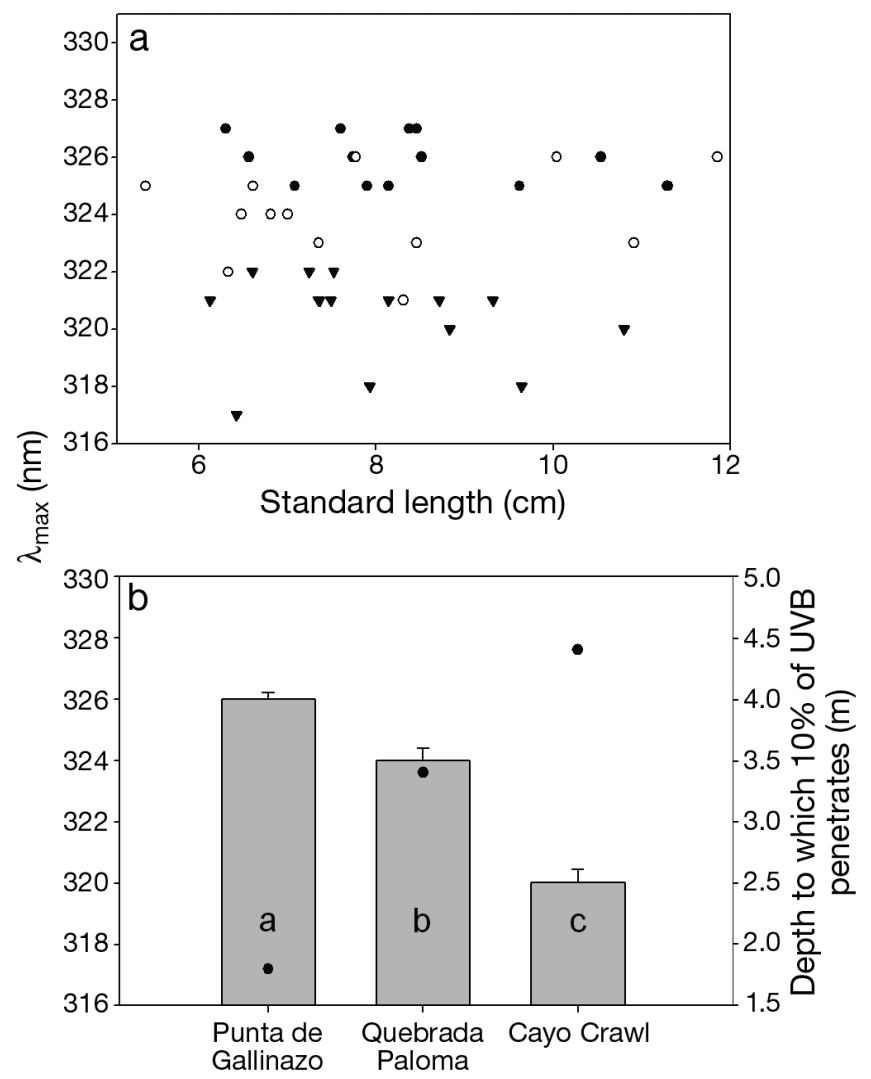

Fig. 5. Halichoeres bivittatus. Wavelength of maximum absorbance of the mucus $\left(\lambda_{\max }\right)$. (a) Standard length vs. $\left(\lambda_{\max }\right)$ by site of capture (GLM: $\left.F_{1,38}=0.15, \mathrm{p}=0.7\right)$. $\bullet$ : Punta de Gallinazo; O: Quebrada Paloma; $\boldsymbol{\nabla}$ : Cayo Crawl. (b) $\lambda_{\max }$ (GLM: $F_{2,38}=57.8, \mathrm{p}<0.0001$ ) and irradiance data. Bars: $\lambda_{\max }$ (mean $+\mathrm{SE}) ; \cdot$ : depth to which $10 \%$ of UVB irradiance penetrates. Letters on bars indicate statistically significant groupings

Aarup 2002, Neil et al. 2002). The irradiance measurements taken in the present study certainly reflected this trend. The 3 sites surveyed showed a gradient of water column UVB attenuation: $k_{\mathrm{d}}(310)$ ranged from $1.83 \mathrm{~m}^{-1}$ at the site closest to 2 large rivers (Punta de Gallinazo) to $0.94 \mathrm{~m}^{-1}$ at the offshore site (Cayo Crawl), where there was no freshwater influx in the immediate vicinity. These values fall between those calculated for extremely clear waters, such as the central equatorial Pacific $\left(0.15 \mathrm{~m}^{-1}\right)$, and those calculated for the Baltic Sea (3.0 to $3.5 \mathrm{~m}^{-1}$; Kirk 1994), approximately equivalent to those measured $50 \mathrm{~km}$ off of the mouth of the Mississippi River in April 1987 and February 1988 (Højerslev \& Aarup 2002).

The geographic scale of riverine influence on seawater transparency may vary greatly. In an extreme example, the Orinoco River in flood affects the transparency of the eastern Caribbean hundreds of kilometers from the river mouth (Blough et al. 1993). In con- 


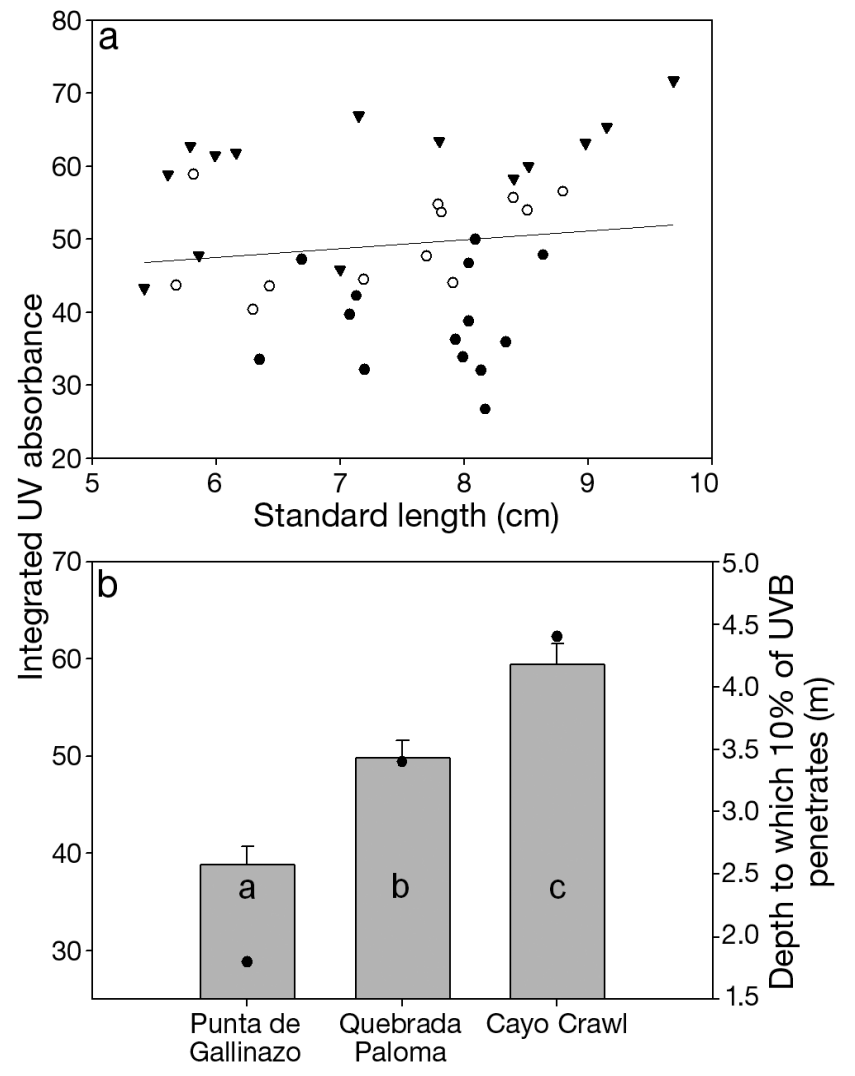

Fig. 6. Scarus iseri. Integrated UV absorbance of the mucus. (a) Standard length vs. integrated absorbance, by site of capture (GLM: $\left.F_{1,36}=7.2, \mathrm{p}=0.01\right)$. •: Punta de Gallinazo; O: Quebrada Paloma; $\mathbf{\nabla}$ : Cayo Crawl. (b) Integrated UV absorbance of mucus (GLM: $F_{2,36}=35.1, \mathrm{p}<0.001$ ) and irradiance data. Bars: integrated absorbance (mean $+\mathrm{SE})$; $\bullet$ : depth to which $10 \%$ of UVB irradiance penetrates. Letters on bars indicate statistically significant groupings

trast, sediment from a river plume parallel to the coast on the Great Barrier Reef was modeled to settle to $20 \mathrm{~m}$ depth only $20 \mathrm{~km}$ from shore (Neil et al. 2002). Clearly, precipitation and other factors affect the precise optical qualities of seawater on a daily or hourly basis, but the trend of increasing seawater clarity relative to distance from large sources of riverine input should remain stable. Owing to the relatively site-attached behavioral habits of the fish species used in this study (see 'Introduction'), it is reasonably certain that the fishes captured spent the majority of their time in habitats reflective of the irradiance measurements taken in this study.

\section{Mucus absorbance}

The spectral shape and overall absorbance of the mucus of Scarus iseri and Halichoeres bivittatus fall within the range of values previously found for fishes

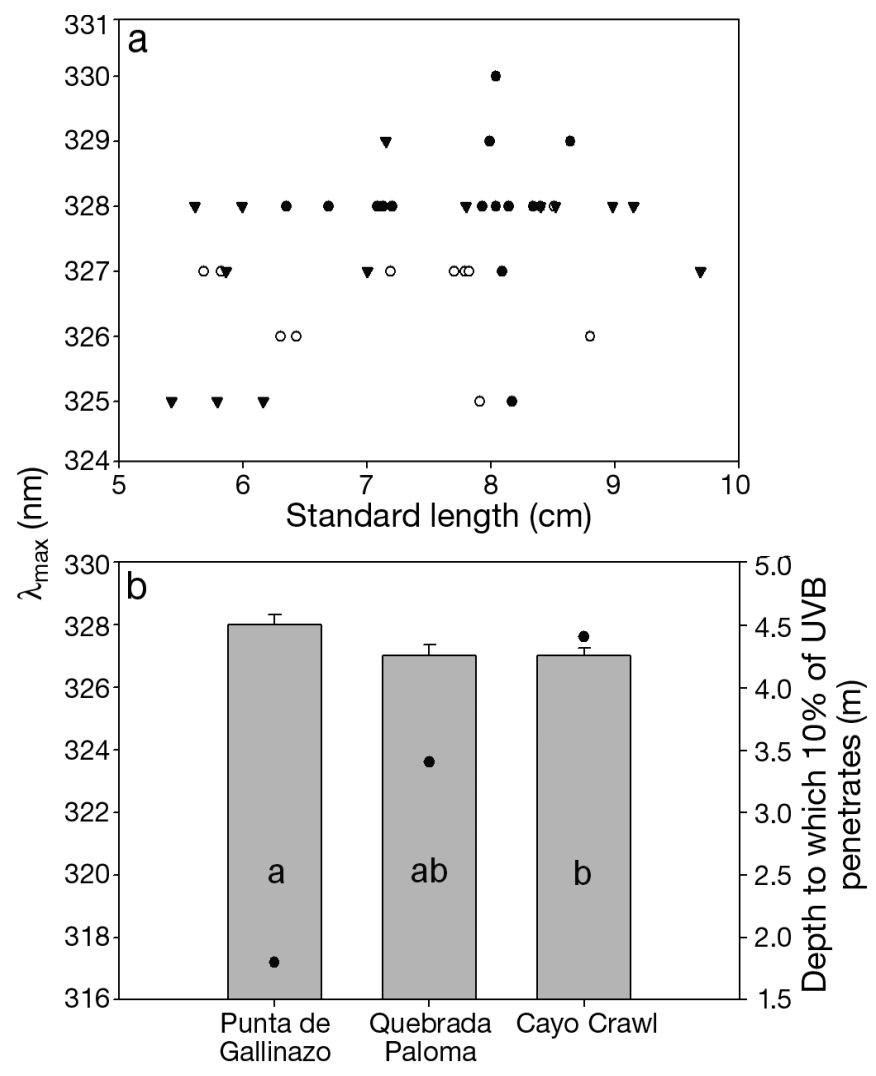

Fig. 7. Scarus iseri. Wavelength of maximum absorbance of the mucus $\left(\lambda_{\max }\right)$. (a) Standard length vs. $\lambda_{\max }$, by site of capture (GLM: $F_{1,36}=3.52, \mathrm{p}=0.07$ ). $\bullet$ : Punta de Gallinazo; O: Quebrada Paloma; $\boldsymbol{\nabla}$ : Cayo Crawl. (b) $\lambda_{\max }$ (GLM: $F_{2,36}=$ $3.61, \mathrm{p}<0.05)$ and irradiance data. Bars: $\lambda_{\max }($ mean $+\mathrm{SE}) ; \bullet$ depth to which $10 \%$ of UVB irradiance penetrates. Letters on bars indicate statistically significant groupings

from Hawaii and the Great Barrier Reef (Zamzow \& Losey 2002, Zamzow 2004, Zamzow \& Siebeck 2006). The compounds responsible for the absorbance peaks at wavelengths longer than $300 \mathrm{~nm}$ are likely to be MAAs. These sunscreen compounds are nearly ubiquitous in marine organisms (Cockell \& Knowland 1999, Shick \& Dunlap 2002), and have been found in fish mucus (Zamzow 2004). The $295 \mathrm{~nm}$ secondary peak present in $S$. iseri mucus spectra may result from deoxygadusol $\left(\lambda_{\max }=294 \mathrm{~nm}\right)$, a compound biochemically similar to MAAs that has been isolated from fish eggs (Plack et al. 1981).

The mucus of Scarus iseri absorbed far more UV than that of Halichoeres bivittatus. Because MAAs are acquired by fishes from their diet (Mason et al. 1998, Zamzow 2004), this may be a consequence of dietary availability. MAAs are synthesized by algae and cyanobacteria, the primary food sources of $S$. iseri (Randall 1967). In contrast, $H$. bivittatus must acquire its MAAs from the wide variety of benthic inverte- 
brates (crabs, urchins, brittle stars, polychaete worms, molluscs, shrimps, chitons, stomatopods) that it consumes (Randall 1967, Wainwright 1988, Dunlap \& Shick 1998). Because animals are incapable of synthesizing MAAs (Dunlap \& Shick 1998), these prey items must in turn acquire MAAs from algae or cyanobacteria, as was previously observed (Carroll \& Shick 1996, Newman et al. 2000, Whitehead et al. 2001). There may be some loss in efficiency of UV-compound sequestration between trophic levels that led to the very different UV absorbance levels recorded for each species in this study. Further research into the efficiency of trophic transfer of MAAs up the food chain would be valuable.

\section{Halichoeres bivittatus}

The integrated absorbance of Halichoeres bivittatus mucus was correlated with fish size (Fig. 4). This positive correlation between UV absorbance of the mucus and fish size has been shown previously for wrasse (Zamzow 2004) and damselfish (Zamzow \& Siebeck 2006). H. bivittatus shows an ontogenetic dietary shift from soft-bodied invertebrate prey to hard-bodied invertebrate prey at a size of approximately 8 to $11 \mathrm{~cm}$ (Wainwright 1988). While UV absorbance of $H$. bivittatus mucus increased with size, no obvious demarcation or change in the rate of increase that would correlate with this dietary shift was observed (Fig. 4). Furthermore, $\lambda_{\max }$ does not correlate with size in $H$. bivittatus (Fig. 5). Hence, it seems unlikely that ontogenetic increases in mucus UV absorbance are a simple consequence of dietary availability in $H$. bivittatus.

Only wavelength of maximum absorbance of Halichoeres bivittatus mucus showed a significant difference among capture sites. The $\lambda_{\max }$ exhibited strong differences among sites, with the shortest-wavelength UV absorbance peaks at Cayo Crawl, the offshore site where short wavelength UV penetrated best (Figs. $2 \& 5$ ). The $\lambda_{\max }$ as well as the plasticity in terms of wavelength shifting among sites, suggests that this single absorbance peak represents a mixture of 2 UVabsorbing compounds, as was previously hypothesized for a Great Barrier Reef damselfish (Zamzow \& Siebeck 2006). Palythine $\left(\lambda_{\max }=320 \mathrm{~nm}\right)$ and asterina-330 $\left(\lambda_{\max }\right.$ $=330 \mathrm{~nm}$ ) were found previously in fish mucus (Zamzow 2004), and are 2 of only 4 MAAs found in a broad survey of the eyes of coral reef fishes (Dunlap et al. 1989). These may be the compounds responsible for the UV absorbance of $H$. bivittatus mucus. If this is true, then the $\lambda_{\max }$ of mucus from Cayo Crawl would indicate more palythine and less asterina-330, whereas the $\lambda_{\max }$ of mucus from Punta de Gallinazo would indi- cate more asterina-330 and less palythine, perhaps achieved via differential sequestration of these compounds from the diet. The shorter the wavelength of light, the more energy the photons possess, and the more damaging the radiation is to biological systems (Setlow 1974, Williamson et al. 2001). Thus, simply shifting the $\lambda_{\max }$ of the mucus toward the shorter end of the UV spectrum should afford greater functional biological protection to $H$. bivittatus, even in the absence of any overall increase in integrated UV absorbance. An alternate explanation that must be considered is that $H$. bivittatus captured at Cayo Crawl may have a diet that differs from those from Punta de Gallinazo. A difference in dietary availability of MAAs could result in wavelength shifting without differential sequestration, as was suggested for captive damselfish in Australia (Zamzow \& Siebeck 2006).

\section{Scarus iseri}

The integrated UV absorbance of Scarus iseri mucus also showed a positive correlation with fish size (Fig. 6). Moreover, for this species, the site of capture was strongly correlated with the integrated UV absorbance of the mucus. Fish from the turbid, inshore site (Punta de Gallinazo) had less sunscreen in the mucus than did conspecifics captured at Quebrada Paloma, which in turn had markedly less sunscreen than fish from the clearer, offshore site (Cayo Crawl). This pattern indicates acclimatization to the local environmental UV irradiance conditions at depths of $1 \mathrm{~m}$ or greater. While there was a statistically significant difference in the wavelength of maximum absorbance of $S$. iseri mucus between Punta de Gallinazo and Cayo Crawl, the difference between the least-squares means was only $1.1 \mathrm{~nm}$. Such a small wavelength shift is of doubtful significance in terms of protection of biological systems. There was no relationship between fish size and wavelength of maximum absorbance.

One may ask, why don't Scarus iseri from every site have similarly high levels of sunscreen? Zamzow (2004) showed in laboratory studies that, when protected from UV radiation, Hawaiian wrasse would lose sunscreen from their mucus despite being provided a dietary source of MAAs. In the same experiment, fish that were exposed to solar UV and provided identical dietary MAAs significantly increased the UV absorbance of their mucus. From these observations, and the fact that MAAs must constantly be sequestered in the mucus as it sloughs into the water column, Zamzow (2004) hypothesized that there may be a cost to the sequestration of sunscreening compounds in the mucus. The data indicated that experi- 
mental fish did not sequester compounds from the diet unless it was necessitated by environmental conditions, presumably to combat UV-induced damage. The present $S$. iseri data are consistent with the hypothesis that fish from turbid, inshore waters sequestered significantly less UV-absorbing compounds into their mucus than did fish from the clearer, offshore sites.

An alternate explanation for the differences observed in integrated absorbance of Scarus iseri mucus from the 3 sites might be that the differences are a simple reflection of differences in the concentrations of MAAs in the diet. I consider this to be unlikely for 2 reasons: (1) algae, the diet of $S$. iseri, nearly always have very high levels of MAAs (Karsten et al. 1998a,b, Jeffrey et al. 1999); and (2) pilot studies have shown fish to be extremely efficient at extracting MAAs from diets with very low MAA concentrations (J. Zamzow unpubl. data). Nonetheless, determining whether dietary concentrations of MAAs affect resultant sunscreen levels in the mucus should be addressed in future experiments.

\section{CONCLUSIONS}

The UV attenuation of inshore waters in the Bahia Almirante area varies greatly. Two species of fish that live in all turbidity zones appear to have adapted to the environmental conditions by utilizing 2 different strategies. Halichoeres bivittatus adapts to increased short-wavelength irradiance by shifting the absorbance of its mucus toward shorter wavelengths, whereas Scarus iseri responds to the same irradiance increase by increasing the overall absorbance of its mucus, but not by markedly shifting the wavelength of maximal absorbance.

Acknowledgements. Many thanks are due the staff of the Smithsonian Tropical Research Institute (STRI) at Bocas del Toro, especially for help with boat piloting and fish capture, and to R. Collin for general logistic support. Fig. 1 was graciously provided by K. Keller in the 11th hour. This research was made possible by a travel grant from STRI-Bocas del Toro.

\section{LITERATURE CITED}

Blough NV, Zafiriou OC, Bonilla J (1993) Optical absorption spectra of waters form the Orinoco River outflow: terrestrial input of colored organic matter to the Caribbean. J Geophys Res 98:2271-2278

Carroll AK, Shick JM (1996) Dietary accumulation of UVabsorbing mycosporine-like amino acids (MAAs) by the green sea urchin (Strongylocentrotus droebachiensis). Mar Biol 124:561-569
Cockell CS, Knowland J (1999) Ultraviolet radiation screening compounds. Biol Rev 74:311-345

Dunlap WC, Shick JM (1998) Ultraviolet radiation-absorbing mycosporine-like amino acids in coral reef organisms: a biochemical and environmental perspective. J Phycol 34: 418-430

Dunlap WC, Williams DM, Chalker BE, Banaszak AT (1989) Biochemical photoadaptation in vision: UV-absorbing pigments in fish eye tissues. Comp Biochem Physiol B 93: 601-607

Højerslev NK, Aarup T (2002) Optical measurements on the Louisiana Shelf off the Mississippi River. Estuar Coast Shelf Sci 55:599-611

Jeffrey SW, MacTavish HS, Dunlap WC, Vesk M, Groenewoud K (1999) Occurrence of UVA- and UVB-absorbing compounds in 152 species (206 strains) of marine microalgae. Mar Ecol Prog Ser 189:35-51

Jerlov NG (1968) Optical oceanography. Elsevier, Amsterdam

Jones KMM (2005) Home range areas and activity centres in six species of Caribbean wrasses (Labridae). J Fish Biol 66: 150-166

Karsten U, Sawall T, Hanelt D, Bischof K, Figueroa FL, FloresMoya A, Wiencke C (1998a) An inventory of UV-absorbing mycosporine-like amino acids in macroalgae from polar to warm-temperate regions. Bot Mar 41:443-453

Karsten U, Sawall T, Wiencke C (1998b) A survey of the distribution of UV-absorbing substances in tropical macroalgae. Phycol Res 46:271-279

Kirk JTO (1994) Optics of UV-B radiation in natural waters. Arch Hydrobiol 43:1-16

Lesser MP, Farrell JH, Walker CW (2001) Oxidative stress, DNA damage and p53 expression in the larvae of Atlantic cod (Gadus morhua) exposed to ultraviolet (290-400 nm) radiation. J Exp Biol 204:157-164

Lou J, Ridd PV (1997) Modelling of suspended sediment transport in coastal areas under waves and currents. Estuar Coast Shelf Sci 24:1-16

Mason DS, Schafer F, Shick JM, Dunlap WC (1998) Ultraviolet radiation-absorbing mycosporine-like amino acids (MAAS) are acquired from their diet by medaka fish (Oryzias latipes) but not by SKH-1 hairless mice. Comp Biochem Physiol A 120:587-598

Neil DT, Orpin AR, Ridd PV, Yu B (2002) Sediment yield and impacts from river catchments to the Great Barrier Reef lagoon. Mar Freshw Res 53:733-752

Newman SJ, Dunlap WC, Nicol S, Ritz D (2000) Antarctic krill (Euphausia superba) acquire a UV-absorbing mycosporine-like amino acid from dietary algae. J Exp Mar Biol Ecol 255:93-110

Newson M (1994) Hydrology and the river environment. Oxford University Press, Oxford

Ogden JC, Buckman NS (1973) Movements, foraging groups, and diurnal migrations of the striped parrotfish Scarus croicensis Bloch (Scaridae). Ecology 54:589-596

Plack PA, Fraser NW, Grant PT, Middleton C, Mitchell AI, Thomson RH (1981) Gadusol, an enolic derivative of cyclohexane-1,3-dione present in the roes of cod and other marine fish. Biochem J 199:741-747

Randall JE (1967) Food habits of reef fishes of the West Indies. Stud Trop Oceanogr 5:665-847

Setlow RB (1974) The wavelengths in sunlight effective in producing skin cancer: a theoretical analysis. Proc Natl Acad Sci USA 71:3363-3366

Shick JM, Dunlap WC (2002) Mycosporine-like amino acids and related gadusols: biosynthesis, accumulation, and UV-protective functions in aquatic organisms. Annu Rev Physiol 64:223-262 
Siebeck O, Vail TL, Williamson CE, Vetter RD and 7 others (1994) Impact of UV-B radiation on zooplankton and fish in pelagic freshwater ecosystems. Arch Hydrobiol 43:101-114

Wainwright PC (1988) Morphology and ecology: functional basis of feeding constraints in Caribbean Labrid fishes. Ecology 69:635-645

Whitehead K, Karentz D, Hedges JI (2001) Mycosporine-like amino acids (MAAs) in phytoplankton, a herbivorous pteropod (Limacina helicina), and its pteropod predator (Clione antarctica) in McMurdo Bay, Antarctica. Mar Biol 139:1013-1019

Williamson CE, Neale PJ, Grad G, De Lange HJ, Hargreaves BR (2001) Beneficial and detrimental effects of UV on aquatic organisms: implications of spectral variation. Ecol Appl 11:1843-1857

Zagarese H, Williamson CE (2001) The implications of solar

Editorial responsibility: Howard Browman (Associate Editorin-Chief), Storebø, Norway
UV radiation exposure for fish and fisheries. Fish Fish (Oxf) 2:250-260

Zamzow JP (2003) Ultraviolet-absorbing compounds in the mucus of temperate Pacific tidepool sculpins: variation over local and geographic scales. Mar Ecol Prog Ser 263: $169-175$

Zamzow JP (2004) Effects of diet, ultraviolet exposure and gender on the ultraviolet absorbance of fish mucus and ocular structures. Mar Biol 144:1057-1064

Zamzow JP, Losey GS (2002) Ultraviolet radiation absorbance by coral reef fish mucus: photo-protection and visual communication. Environ Biol Fish 63:41-47

Zamzow JP, Siebeck UE (2006) Ultraviolet absorbance of the mucus of a tropical damselfish (Pomacentrus amboinensis Bleeker): effects of ontogeny, captivity and disease. J Fish Biol 69:1583-1594

Submitted: September 1, 2006; Accepted: January 22, 2007 Proofs received from author(s): July 18, 2007 